\title{
Short Communication: Assessing phytoplankton species structure in trophically different water bodies of South Ural, Russia
}

\author{
ANASTASIYA KOSTRYUKOVA ${ }^{1, \bullet}$, IRINA MASHKOVA ${ }^{1}$, SERGEY BELOV ${ }^{1}$, ELENA SHCHELKANOVA ${ }^{2}$, \\ VIKTOR TROFIMENKO ${ }^{3}$ \\ ${ }^{1}$ Department of Chemistry, Institute of Natural Sciences and Mathematics, South Ural State University. 76 Lenin Prospect, 454080 Chelyabinsk, Russia. \\ Tel./Fax. +7-351-2679517, vemail: kostriukovaam@susu.ru \\ ${ }^{2}$ Institute of Linguistics and International Communications, South Ural State University. 76 Lenin Prospect, 454080 Chelyabinsk, Russia \\ ${ }^{3}$ Department of Philosophy and Culturology, South Ural State Humanitarian Pedagogical University. 69 Lenin Prospect, 454080 Chelyabinsk, Russia
}

Manuscript received: 6 April 2021. Revision accepted: 29 July 2021.

\begin{abstract}
Kostryukova A, Mashkova I, Belov S, Shchelkanova E, Trofimenko V. 2021. Short Communication: Assessing phytoplankton species structure in trophically different water bodies of South Ural, Russia. Biodiversitas 22: 3530-3538. The study aims to analyze the species structure of the phytoplankton communities of four water bodies in South Ural (Lakes-Turgoyak, Uvildy, Ilmenskoe and Shershnevskoe reservoir). These water bodies are characterized by different trophic states and levels of anthropogenic impact. Lake Turgoyak is oligotrophic; Lake Uvildy is oligomesotrophic. Both water bodies are protected areas and natural monuments. But tourism and recreation are not prohibited on their territories. The mesoeutrophic Lake Ilmenskoe is partially located within the Ilmen State Reserve, and it experiences less anthropogenic impact. The eutrophic Shershnevskoe reservoir is located within the boundaries of the city of Chelyabinsk. It is used as a source of drinking water. Cyanobacteria was the dominant division in the eutrophic Shershnevskoe reservoir. Bacillariophyta dominated in the plankton communities in oligotrophic Lake Turgoyak and oligomesotrophic Lake Uvildy. Green and blue-green algae biodiversity increased in the oligomesotrophic Lake Uvildy. For the mesoeutrophic Lake Ilmenskoe, diatom algae are dominant, but a higher proportion of Chlorophyta (especially Cyanobacteria) was revealed. Species similarity among phytoplankton communities in the given lakes was studied through cluster analysis based on the Sorensen-Czekanowski coefficient. The higher level of similarity between plankton species compositions could be explained by their locality rather than their trophic status.
\end{abstract}

Keywords: Biodiversity, species structure, Lake Turgoyak, Lake Uvildy, Lake Ilmenskoe, phytoplankton, Shershevskoe Reservoir

\section{INTRODUCTION}

All living communities naturally change their structure, and algae is not an exception (Ansari and Gill 2014; Paulino et al. 2018; Bazarova et al. 2019). This change is a rather long process, and there is no singular opinion on the reasons for transformations in species structure. However, human activity has a significant impact on the succession of phytoplankton communities (Setyono and Himawan 2018; Mashkova et al. 2020a; Namsaraev et al. 2020). Phytoplankton responds quickly to changes in its aquatic environment, which allows it to be used as a bioindicator. Microalgae are also very sensitive and respond quickly to decreased water quality caused by human activity (Setyono and Himawan 2018). Eutrophication, which influences aquatic biodiversity, affects many water bodies around the world and is considered a global issue (Ansari and Gill 2013; Ismest'eva et al. 2015; Viaroli et al. 2015; Gao et al. 2020; Pratiwi et al. 2020). Eutrophication leads to higher trophic states. Increased biogenic element intake from a catchment area due to human activity leads to the transformation of phytoplankton community structure, changes in season dynamics of the biomass and the increased significance of some species (Snit'ko 2009; Suda et al. 2016; Pratiwi et al. 2018; Song et al. 2019; Wang et al. 2020; Yang et al. 2020). Pearsall (1932) first defined the main transformations in lake algae composition after enrichment by biogenic elements. He studied nine lakes in England with well-defined plankton types. Among them were rocky lakes with primarily green plankton, silted lakes with primarily blue-green algae and lakes with primarily diatoms. Pearsall revealed the following pattern in his work: the communities change from a predominance of yellow-green algae (Chrysophyta), desmid algae (Chlorophyta Desmidiales) and diatom (Baccilariophyta) with low biomass to a predominance of blue-green (Cyanobacteria) with high biomass (Snit'ko 2009). Rakocevic-Nedovic and Hollert (2005) registered the qualitative dominance of Chlorophyta and Bacillariophyta in the mesotrophic Lake Scadar (Montenegro, Balkan) throughout the year of study. Diatoms dominated in spring with the population peak in May (Rakocevic-Nedovic and Hollert 2005). In summer they remained quite numerous. However, in June, green algae became dominant. Bluegreen algae dominated the community late in summer with the population peak reached in August. Diatoms were dominant again in winter (Rakocevic-Nedovic and Hollert 2005). Ayoade et al. (2019) marked the abundance of Cyanophyta and Chlorophyta in eutrophic water bodies from April till October. 
The Chelyabinsk region (part of the South Ural region) is an industrial and agricultural zone with 88.5 thousand $\mathrm{m}^{2}$ of land. It is located on the border of Europe and Asia in the southern part of the Urals and on the adjusting West Siberian plain (Figure 1). The major industries are iron and steel, mechanical engineering, non-ferrous industry (copper, zinc, and nickel production), chemical production and others. These industries have a negative impact on the environment (Ministry of Ecology of the Chelyabinsk Region 2019). The Chelyabinsk region has more than 3000 water bodies (Levit 2005). Of these numerous water bodies, only 100 have a surface area of more than $5 \mathrm{~km}^{2}$. The region's water bodies are predominantly smaller than 1 $\mathrm{km}^{2}$ in surface area. Most of the large lakes are widely used for recreation (Besedin et al. 2000; Veisberg et al. 2015; Zakharov 2018).

The natural water bodies of Chelyabinsk region are closely studied. The human impact on water bodies and their shores and, on flora and fauna (phytoplankton and zooplankton communities, macrophytes, mollusks and fish) are assessed. The changing chemical indices of water receive a great deal of attention. The studies are comprehensive and give a full review of water bodies. The trophic status of South Ural water bodies has been widely studied using different methods. Mashkova et al. (2021) researched the trophic status of the Chelyabinsk region water bodies by the zooplankton community. The ecological state of aquatic ecosystems was repeatedly studied using qualitative and quantitative methods to assess phytoplankton (Kostryukova et al. 2019, 2020). But there is little significant research on phytoplankton communities in Chelyabinsk region water bodies. The most important works are by Snit'ko and Sergeeva (2003), Yarushina et al. (2004). They provided the general characteristics of plankton in the region and studied the specific features of the species composition and taxonomic structure of algae communities. Snit'ko (2009) provided information on phytoplankton in various South Ural water bodies subject to human impact.

The composition and structure of phytoplankton in water bodies show the status of the water system. With increased human impact on water bodies, the structure, population size and biomass of phytoplankton change. The study aims to study possible relations between the changes of species structure of phytoplankton community and the trophic status of water bodies.

\section{MATERIALS AND METHODS}

\section{Study area}

Four water bodies in the South Ural region with different trophic status were selected for study: Turgoyak, an oligotrophic lake; Uvildy, an oligomesotrophic lake; Ilmenskoe, a mesoeutrophic lake; and the Shershnevskoe reservoir, a eutrophic water body (Figure 1).

\section{Characteristics of water bodies}

The morphology of the water bodies is given in Table 1 . Turgoyak and Uvildy are large and deep lakes with a surface area of over $10 \mathrm{~km}^{2}$ and a depth of more than 20 $\mathrm{km}$. Ilmenskoe is medium-sized (1-10 $\left.\mathrm{km}^{2}\right)$ but shallow. The water surface area of the Shershnevskoe reservoir allows for its classification as a large lake, but it is shallow (Snit'ko 2009). According to the chemical composition, the lakes belong to the hydrocarbonate class of the calcium group (Snit'ko 2009). All the chosen lakes and the Shershnevskoe reservoir are freshwater bodies. The salinity of Turgoyak and Ilmenskoe does not exceed $300 \mathrm{mg} . \mathrm{L}^{-1}$, Uvildy is measured at $370-390 \mathrm{mg} . \mathrm{L}^{-1}$, and the Shershnevskoe reservoir - 400-500 mg.L-1 (Snit'ko 2009).

\section{Anthropogenic impact on water bodies}

Lake Turgoyak is near the city of Miass (population $>150,000$ ). Automobile building is the predominant industry. Lake Turgoyak was recognized as a natural monument in 1969. Natural monuments are created to preserve small areas of valuable natural objects. Environmental, scientific, educational and recreational activities are allowed on their territory. They are actively used for sightseeing, tourism and recreation (Federal Law 1995). Lake Turgoyak experiences an adverse human impact from recreation, with 50,000-100,000 tourists visiting each year (Zakharov 2018). Water from Lake Turgoyak was used for economic needs from 1952 untill the early 1990-s. The water intake exceeded the average water balance of the lake for many years, i.e. more than 5-6 mlnm ${ }^{3}$ year $^{-1}$ (Zakharov 2018).

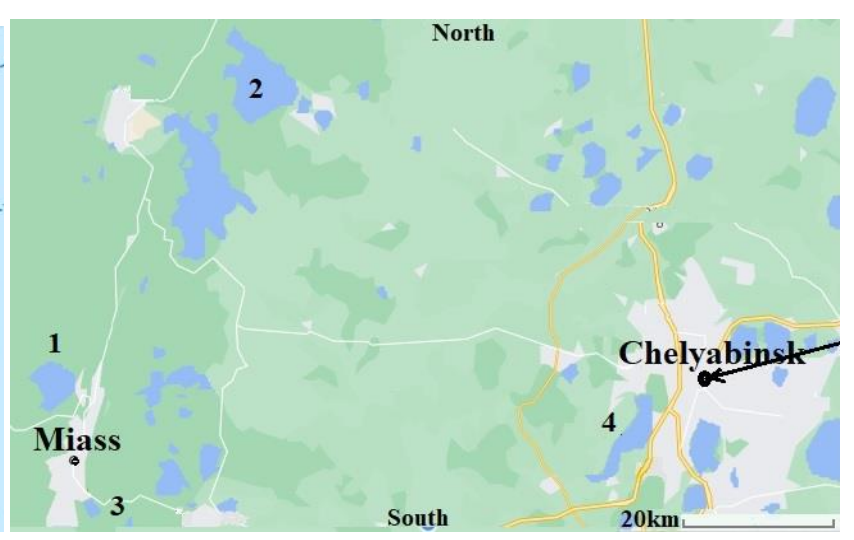

Figure 1. Map of Chelyabinsk region, Russia with locations of the studied lakes: 1. Lake Turgoyak, 2. Lake Uvildy, 3. Lake Ilmenskoe, 4. Shershnevskoe reservoir 
Table 1. Morphological parameters of water bodies.

\begin{tabular}{lccccc}
\hline \multirow{2}{*}{ Water bodies } & Elevation & Water surface & Water volume & \multicolumn{2}{c}{ Depth $(\mathbf{m})$} \\
\cline { 4 - 6 } & $(\mathbf{m}$ asl.) & $\mathbf{a r e a}\left(\mathbf{k m}^{\mathbf{2}}\right)$ & & Maximal & Average \\
\hline Turgoyak (oligotrophic lake) & 318.9 & 26.40 & 507.0 & 34.5 & 19.2 \\
Uvildy (oligomesotrophic lake) & 272.0 & 68.10 & 1014.0 & 38.0 & 13.0 \\
Ilmenskoe (mesoeutrophic lake) & 331.4 & 4.56 & 14.6 & 6.1 & 3.0 \\
Shershnevskoe (eutrophic reservoir) & 222.0 & 39.00 & 160.0 & 14.0 & 4.0 \\
\hline
\end{tabular}

Lake Uvildy is the largest lake in the South Ural region. There are many villages, resorts and recreation centres on its shores. The lake is exposed to an adverse human impact from recreation. It has been listed as a natural monument since 1969. Around a quarter of the lake water was pumped into the Argazinskoe reservoir to supply the city of Chelyabinsk with drinking water. The water level decreased almost by $4 \mathrm{~m}$. Trees and shrubs grew on the drained land and were subsequently drowned in 2006 when the water level was restored. This resulted in eutrophication.

Lake Ilmenskoe is partially located in the Ilmen State Reserve and on the eastern shore of the city of Miass. A road and a railway run along the northern and eastern shores. There is a recreational area on the west shore. The southern shore is swampy.

The Shershnevskoe reservoir is located in Chelyabinsk and serves as a water source. It was filled with water from 1965-1969. There are numerous resorts, cottages and residential areas on its watershed. As a result, it experiences an adverse human impact (Kostryukova et al. 2019; Kostryukova et al. 2020; Mashkova et al. 2020b).

\section{Identification of phytoplankton species}

The study is based on our own collected data, as well as on the data of other researchers studying phytoplankton of these water bodies. The species composition of phytoplankton communities was identified: (i) for Turgoyak-according to research data from 1998-2006 (Snit'ko 2009; Snit'ko and Snit'ko 2012; Yarushina et al. 2004); (ii) for Uvildy-according to research data from (2005-2006) (Snit'ko and Sergeeva 2003; Yarushina et al. 2004) and our research (2014-2016); (iii) for Ilmenskoeaccording to research data from 1998-2003 (Snit'ko and Sergeeva 2003; Snit'ko 2009; Yarushina et al. 2004) and our research in 2011-2016; (iv) for Shershnevskoe reservoir-according to research data from (2005-2006) (Snit'ko and Sergeeva 2003; Yarushina et al. 2004) our research (2014-2016). At each site, samples were collected and filtered through a plankton net (mesh size: $100 \mu \mathrm{m}$ ). The retained organisms were transferred into glass containers. The collected material was preserved in $5 \%$ formalin.

Non-diatom algae were analyzed using a magnification of 600× (Altami BIO 2T microscope, Altami Ltd., St. Petersburg, Russia). Permanent diatom slides were prepared after oxidizing the organic material (by nitric acid and sulfuric acid), and at least 300 valves were counted for each sample using an Altami BIO 2T microscope at 1000x under oil immersion.

Species were identified using handbooks (Al-Kandari et al. 2009; Yarushina et al. 2004). Taxonomic characteristics were specified following algae determinants (Guiry and Guiry 2020; WoRMS 2019).

The dominant species included those species whose frequency of occurrence on the Starmach scale (Starmach 1963) was more than 30 organisms in the specimen. The frequency of occurrence of organisms of a certain species on the Starmach scale is estimated as follows (Table 2).

\section{Data analysis}

We chose the cluster analysis method to study the species similarity of the phytoplankton communities of the studied lakes. The data were analyzed using the SorensenChekanowski coefficient of species similarity:

$$
\mathrm{Is}=2 \mathrm{c} /(\mathrm{a}+\mathrm{b})
$$

Where: $a$ is the number of species in one community; $b$ is the number of species in another community; $\mathrm{c}$ is the number of species common to the two communities. The limits of this coefficient are from 0 to $100 \%$, where $100 \%$ is a complete similarity of communities (the absolute coincidence of lists), and $0 \%$ means that they have no common species.

Table 2. The frequency of occurrence of organisms of a certain species on the starmach scale

\begin{tabular}{lcl}
\hline The frequency of occurrence of organisms & Points & Characteristics \\
\hline The species is not present in every specimen & + & Sporadically \\
1-6 organisms in the specimen & 1 & Very rarely \\
7-16 organisms in the specimen & 2 & Rarely \\
17-30 organisms in the specimen & 3 & Often \\
31-50 organisms in the specimen & 4 & Very often \\
31-50 organisms in the specimen & 5 & Absolute predominance, absolute predominance \\
\hline
\end{tabular}




\section{RESULTS AND DISCUSSION}

\section{Results}

The results are presented in a dendrogram. Dendrograms are used to compare the taxonomic composition of algae of different water bodies or different areas of the same water body (Barinova and Smith 2019; Komulaynen 2018; Malakhov et al. 2017). The dendrogram was calculated using a special comparative floristic program GRAPHS (Nowakowski 2004).

The largest number of microalgae species in Lake Turgoyak are from four main divisions: Bacillariophyta, Charophyta, Chlorophyta, and Cyanobacteria. When comparing the taxonomic composition (Figure 2), we discovered that the microalgae of the Bacillariophyta division played a key role in the formation of phytoplankton communities of the oligotrophic Lake Turgoyak (about half of all microalgae species of this lake, $44 \%$ of the total number of species). The number of microalgae species of the Charophyta division in this lake is two times fewer ( $21 \%$ of the total number of species). The family Desmidiales (specifically, the genera Cosmarium (10 sp.) and Staurastrum (9 sp.)) determine the higher species diversity of phytoplankton in this group. For the other water bodies, the proportion of species abundance of Cosmarium genus and Staurastrum genus is significantly lower. Desmids are used as indicators of water quality as they are sensitive to any changes in water bodies (Coesel 2001; Aquino et al. 2018). They are typical representatives of the flora of oligotrophic and mesotrophic aquatic systems (Aquino et al. 2018). There are even fewer green microalgae (14\% of the total species number) and blue-green algae ( $8 \%$ of the total species number) in Lake Turgoyak. The other divisions account only for $13 \%$ of the total species number.

\section{Discussion}

According to Snit'ko (2009) and Trifonova (1990) the predominance of the Bacillariophyta division is a characteristic feature of deep mountain lakes, including Turgoyak. A similar pattern of species distribution by divisions is observed, for example, in mountain water bodies of the Ergaki Ridge (Krasnoyarsk Territory) (Makeeva and Denisova 2017). According to these authors, the highest species diversity is characteristic of Bacillariophyta (44\%) and Charophyta (21.2\%). The proportion of Chlorophyta and Cyanobacteria is $14 \%$ and $13.3 \%$, respectively. Bogdanov et al. (2004), Chekryzheva (2017), Trifonova (1990) and Sharov (2020) also note the highest species diversity of diatoms in the majority of oligotrophic and mesotrophic water bodies of the NorthWest region of the European part of Russia, mountain lakes of the Polar Ural region and water bodies of the temperate climate zone.

The highest phytoplankton biodiversity in Lake Turgoyak is characteristic for the following families: Desmidiaceae (24 sp.), Surirellaceae (9 sp.), Naviculaceae (8 sp.), Rhopalodiaceae (7 sp.), Stephanodiscaceae (7 sp.), Fragilariaceae (6 sp.), Cymbellaceae (6 sp.) and Eunotiaceae (6 sp.) (Table 4). They make up $40.1 \%$ of the total species composition of this lake. Analyzing the Genus taxonomic unit, we identified the following genera rich in species: Cosmarium (10 sp.), Staurastrum (9 sp.), Surirella (6 sp.), and Eunotia (6 sp.).

The distribution of microalgae species in the oligomesotrophic Lake Uvildy is different. Bacillariophyta, Chlorophyta and Cyanobacteria had the greatest number of species. They account for $30 \%, 24 \%$ and $24 \%$ of the total number of species respectively (Figure 2). The blue-green microalgae of Lake Uvildy are rich in species, which is not characteristic of this type of mountain water body. Unlike Lake Turgoyak, the proportion of microalgae of the Charophyta division in the species diversity of the community is significantly lower (7\% of the total number of species). The composition of the leading phytoplankton families of Lake Uvildy differs from Lake Turgoyak. The leading algae families of Lake Uvildy are shown in Table 3. The total number of species registered is: Euglenaceae (7 sp.), Desmidiaceae (6 sp.), Aphanizomenonaceae (6 sp.), Oscillatoriaceae (6 sp.), and Hydrodictyaceae (6 sp.). These families include $25.2 \%$ of microalgae species of the total species composition of microalgae in Lake Uvildy. Unlike lake Turgoyak, for Lake Uvildy the genera rich in species include Epithemia (4 sp.) and Euglena (4 sp.).

For the mesoeutrophic Lake Ilmenskoe, diatom algae are dominant accounting for $40 \%$. The proportion of bluegreen and green algae are $22 \%$ and $17 \%$ respectively. The increased proportion of blue-green algae is associated with higher trophic activity and water pollution. The leading algae families of Lake Ilmenskoe (Table 4) include Microcystaceae (7 $\quad$ sp.), Dinobryaceae (7 $\quad$ sp.), Desmidiaceae (7 $\mathrm{sp}$.$) , Gomphonemataceae (7 sp.),$ Naviculaceae (7 sp.), Euglenaceae (6 sp.), and Cymbellaceae (6 sp.). These families include $29.2 \%$ of the total microalgae species composition of Lake Ilmenskoe. The Desmidiaceae family has the highest species diversity in all three lakes (Turgoyak, Uvildy and Ilmenskoe). The genus Dinobryon (6 sp.) is the richest in species.

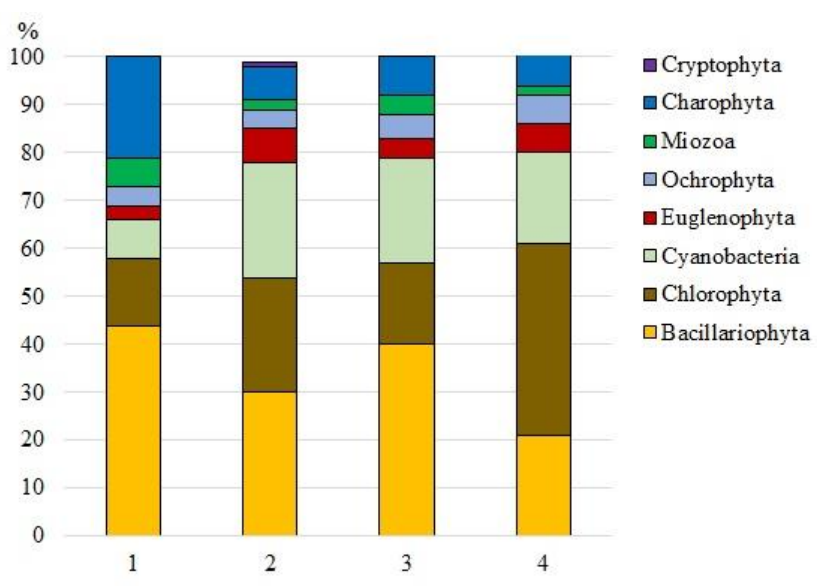

Figure 2. Abundance of microalgae species (\% of total species number) in the studied water-bodies: 1 . Lake Turgoyak, 2. Lake Uvildy, 3. Lake Ilmenskoe, 4. Shershnevskoe reservoir. 
Table 3. Taxonomic composition of phytoplankton communities in the studied water bodies of South Ural, Russia

\begin{tabular}{|c|c|c|c|c|c|}
\hline \multicolumn{2}{|c|}{ Algae taxa } & \multicolumn{4}{|c|}{ Sites } \\
\hline Divisions & Class & Lake Turgoyak & Lake Uvildy & Lake Ilmenskoe & $\begin{array}{c}\text { Shershnevskoe } \\
\text { Reservoir }\end{array}$ \\
\hline \multirow[t]{5}{*}{ Bacillariophyta } & Mediophyceae & 8 & 2 & 4 & 6 \\
\hline & Coscinodiscophyceae & 2 & 2 & 4 & 4 \\
\hline & Bacillariophyceae & 62 & 33 & 55 & 24 \\
\hline & $\begin{array}{l}\text { Bacillariophyta classis } \\
\text { incertae sedis }\end{array}$ & - & - & 1 & - \\
\hline & Total & 72 & 37 & 64 & 34 \\
\hline \multirow[t]{4}{*}{ Chlorophyta } & Chlorophyceae & 18 & 23 & 22 & 50 \\
\hline & Trebouxiophyceae & 4 & 6 & 3 & 13 \\
\hline & Ulvophyceae & - & 1 & 2 & 1 \\
\hline & Total & 22 & 30 & 27 & 64 \\
\hline Cyanobacteria & Cyanophyceae & 13 & 29 & 35 & 31 \\
\hline Euglenozoa & Euglenophyceae & 5 & 9 & 7 & 9 \\
\hline \multirow[t]{4}{*}{ Ochrophyta } & Chrysophyceae & 4 & 4 & 7 & 5 \\
\hline & Xanthophyceae & 2 & 1 & 1 & 2 \\
\hline & Synurophyceae & - & - & - & 2 \\
\hline & Total & 6 & 5 & 8 & 9 \\
\hline Miozoa & Dinophyceae & 10 & 3 & 6 & 3 \\
\hline \multirow[t]{3}{*}{ Charophyta } & Zygnematophyceae & 31 & 9 & 13 & 10 \\
\hline & Klebsormidiophyceae & 3 & - & - & 2 \\
\hline & Total & 34 & 9 & 13 & 12 \\
\hline Cryptophyta & Cryptophyceae & - & 1 & 1 & - \\
\hline Total & & 162 & 123 & 161 & 162 \\
\hline
\end{tabular}

Table 4. Phytoplankton species number in the leading families and genera in the studied water bodies of South Ural, Russia

\begin{tabular}{|c|c|c|c|c|}
\hline Family/genus & $\begin{array}{c}\text { Lake } \\
\text { Turgoyak }\end{array}$ & Lake Uvildy & $\begin{array}{c}\text { Lake } \\
\text { Ilmenskoe }\end{array}$ & $\begin{array}{c}\text { Shershnevskoe } \\
\text { reservoir }\end{array}$ \\
\hline \multicolumn{5}{|l|}{ Bacillariophyta } \\
\hline Surirellaceae/Surirella & $9 / 6$ & $3 / 2$ & $2 / 2$ & $1 / 1$ \\
\hline Naviculaceae/Navicula & $8 / 5$ & $2 / 1$ & $7 / 4$ & $1 / 1$ \\
\hline Stephanodiscaceae & 7 & 1 & 2 & 4 \\
\hline Rhopalodiaceae/Epithemia & $7 / 7$ & $4 / 4$ & $3 / 3$ & $2 / 2$ \\
\hline Fragilariaceae/Fragilaria & $6 / 4$ & $4 / 3$ & $5 / 3$ & $2 / 2$ \\
\hline Cymbellaceae/Cymbella & $6 / 5$ & $3 / 3$ & $6 / 5$ & $1 / 1$ \\
\hline Eunotiaceae/Eunotia & $6 / 6$ & $0 / 0$ & $1 / 1$ & $0 / 0$ \\
\hline Gomphonemataceae/Gomphonema & $2 / 0$ & $2 / 2$ & $7 / 4$ & $3 / 1$ \\
\hline \multicolumn{5}{|l|}{ Charophyta } \\
\hline Desmidiaceae/Staurastrum/Cosmarium & $24 / 9 / 10$ & $6 / 2 / 2$ & $7 / 3 / 3$ & $5 / 4 / 1$ \\
\hline \multicolumn{5}{|l|}{ Chlorophyta } \\
\hline Scenedesmaceae/Desmodesmus/Scenedesmus/Tetradesmus & $2 / 0 / 0 / 0$ & $3 / 0 / 1 / 2$ & $3 / 1 / 0 / 0$ & $16 / 3 / 3 / 4$ \\
\hline Selenastraceae/Monoraphidium & $0 / 0$ & $4 / 2$ & $1 / 0$ & $9 / 4$ \\
\hline Hydrodictyaceae/Tetraedron & $3 / 0$ & $6 / 1$ & $4 / 0$ & $7 / 3$ \\
\hline \multicolumn{5}{|l|}{ Cyanobacteria } \\
\hline Oscillatoriaceae/Oscillatoria & $2 / 1$ & $6 / 4$ & $3 / 2$ & $0 / 0$ \\
\hline Aphanizomenonaceae/Dolichospermum & $4 / 4$ & $6 / 3$ & $5 / 5$ & $9 / 7$ \\
\hline Microcystaceae/Microcystis & $2 / 2$ & $2 / 2$ & $7 / 5$ & $6 / 6$ \\
\hline
\end{tabular}

The eutrophic Shershnevskoe reservoir is marked by the richest species diversity of green algae $(40 \%)$ with the proportions of diatom and blue-green algae, $21 \%$ and $19 \%$ respectively (Figure 2). The water bodies with higher trophic status are characterized by a much scantier composition of diatom plankton and the predominance of green algae in the community (Snit'ko 2009). The obtained results correspond to the previous data (Eremkina 2010), according to which the higher the trophic status of the water body, the richer the biodiversity of green and euglenic algae and the lower the biodiversity of diatoms and dinophytes. Higher species diversity of green algae compared to diatoms was also observed in water bodies of the Middle and Lower Volga, the eutrophic water bodies of the Volga region (Samara region) and Karelia (Chekryzheva 2017; Malysheva et al. 2018; Sharov 2020). The shallow depth of the Shershnevskoe reservoir and the increased biogenic load increased the temperature of the 
water mass and create favorable conditions for the development of green algae.

The leading algae families of the Shershnevskoe reservoir (Table 4) include Scenedesmaceae (16 sp.), Selenastraceae (9 sp.), Aphanizomenonaceae (9 sp.), Hydrodictyaceae (7 sp.) and Phacaceae (6 sp.). These families make up $27.8 \%$ of the species of the total species composition in the Shershnevskoe reservoir. Dolichospermum genus (7 sp.) and Microcystis (6 sp.) are represented more richly in the Shershnevskoe reservoir than in other studied water bodies.

Table 4 shows that 7 families with the highest species abundance (6-9 sp.) were found in the algae of the Bacillariophyta division of the oligotrophic Lake Turgoyak. Moreover, in each family, we identified a genus that determines the species abundance. 4-7 species were registered in each of these leading genera. The exception was the Stephanodiscaceae family which united only oneand two-species genera. This pattern was not observed in other water bodies. The Naviculaceae and Cymbellaceae families preserve a large number of species in Lakes Uvildy and Ilmenskoe. However, in the eutrophic Shershnevskoe reservoir, the species diversity of diatomics is reducing significantly.

The large proportion of the algae of the Charophyta division, particularly of the Desmidiaceae family, is another feature of the phytoplankton species structure of Lake Turgoyak that distinguishes it from other water bodies. The presence of 24 species of this family indicates the oligotrophic status of the lake.

The high species abundance of the Chlorophyta division was only observed in the eutrophic Shershnevskoe reservoir (7-16 sp.). Apparently, the optimal conditions for the development of species of this division have been created in the eutrophic Shershnevskoe reservoir, which allows them to compete with other algae.

There is no clear relationship between species abundance and the trophic status of the water body for the Cyanobacteria division. The families with the least number of species are recorded in the algae community of the oligotrophic Lake Turgoyak.

Thus, four main departments of phytoplankton communities of the studied water bodies could be distinguished, differences in the species diversity of which indirectly reflect changes in the trophic status. Diatoms are the dominant department in terms of species diversity in all three lakes that have a lower level of eutrophication compared to the reservoir. They are often used as indicators of the ecological state of water bodies. On the one hand, developing eutrophication results in an increasing number of planktonic diatoms (Weckström et al. 2007). Weckström et al. 2007 attribute this to a growing water turbidity (due to an increase in the number of suspended particles and the total productivity of plankton), which in turn leads to the creation of more favorable conditions for the development of individual groups of diatoms. On the other hand, eutrophication leads to a decreasing species diversity of algae in this department. The high species richness of microalgae of the Charophyta department can be used as an indicator of the good ecological condition of water bodies. More than 30 species of algae of this department were present in the water of the oligotrophic lake. The species diversity of blue-green algae increases in mesotrophic and eutrophic water bodies. According to Hall and Smol (1999), an increase in the N:P ratio during eutrophication leads to the replacement of small diatoms with larger cyanobacteria, which are more competitive in terms of nitrogen use. For those cyanobacteria that do not fix nitrogen or are less effective nitrogen competitors, their higher diversity in mesotrophic and eutrophic water bodies may be determined by the fact that they are more competitive with respect to light in water bodies with increased turbidity (Downing et al. 2001). A significant predominance of green algae species in the eutrophic reservoir may indicate a deterioration of its ecological status towards hypertrophy (Jensen et al. 1994). Green algae dominate in hypertrophic reservoirs, because in conditions of an excess of nutrients they have higher growth rates and are stronger competitors compared to relatively slow-growing cyanobacteria (Jensen et al. 1994; Ma et al. 2014).

Also, we compared the species composition of algae communities using the comparative floral program GRAPHS (Nowakowski 2004). We designed a dendrogram based on the Sorensen-Chekanowski coefficient (Figure 3). The species composition revealed more similarities between the oligotrophic Lake Turgoyak and the mesoeutrophic Lake Ilmenskoe than with the oligomesotrophic Lake Uvildy. The higher similarity between species compositions of Turgoyak and Ilmenskoe than Turgoyak and Uvildy could be explained by their location not their trophic status. Turgoyak and Ilmenskoe are closer to each other. The taxonomic structure of the algae of the Shershnevskoe reservoir coincides with the structures of other water bodies by just $26 \%$.

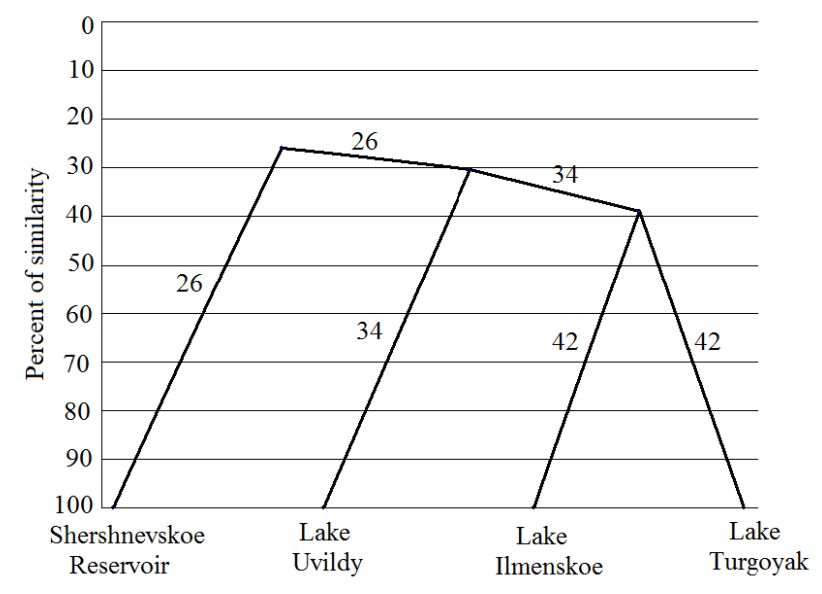

Figure 3. Dendrogram of the similarity of phytoplankton composition in the studied water bodies (Sorensen-Czekanowski coefficient) 
Table 5. Dominant species of phytoplankton composition in the studied water bodies in South Ural, Russia

Species

Bacillariophyta
Asterionella formosa Hassall 1830
Aulacoseira granulata (Ehrenberg) Simonsen 1545
Fragilaria crotonensis Kitton 1865
Fragilaria acus (Kützing) Lange-Bertalot 2000
Epithemia gibba (Ehrenberg) Kützing 1844
Ulnaria ulna (Nitzsch) Compère 2001

Cyanobacteria

Anabaena aequalis O.Borge 1906

Aphanizomenon flos-aquae (Linnaeus) Ralfs ex Bornet \& Flahault 1888

Dolichospermum flosaquae (Brébisson ex Bornet \& Flahault) P.Wacklin, L.Hoffmann \& J.Komárek 2005

Dolichospermum lemmermannii (Ricter) P.Wacklin, L.Hoffmann \& J.Komárek 2005

Dolichospermum macrosporum (Klebhan) Wacklin, L.Hoffmann \& Komárek 2005

Dolichospermum planctonicum (Brunnthaler) Wacklin, L.Hoffmann \& Komárek 2005

Dolichospermum spiroides (Klebhan) Wacklin, L.Hoffmann \& Komárek 2005

Gloeotrichia echinulata P.G.Richter 1854

Microcystis aeruginosa (Kützing) Kützing 1846

Microcystis flosaquae (Wittrock) Kirchner 1858

Microcystis pulverea (H.C.Wood) Forti 1504

Microcystis wesenbergii (Komárek) Komárek ex Komárek 2006

Snowella lacustris (Chodat) Komárek \& Hindák 1588

Planktothrix agardhii (Gomont) Anagnostidis \& Komárek 1588

Johanseninema constrictum (Szafer) Hasler, Dvorák \& Poulícková 2014

Anabaena contorta Bachmann 1521

Chlorophyta

Raphidocelis mucosa (Korshikov) Komarek 1545

Scenedesmus quadricauda (Turpin) Brébisson 1833

Pseudopediastrum boryanum (Turpin) E.Hegewald 2003

Pediastrum duplex Meyen 1825

Ochrophyta

Dinobryon divergens O.E.Imhof 1884

Dinobryon sociale var. americanum (Brunnthaler) Bachmann 1911

Uroglenopsis americana (G.N.Calkins) Lemmermann 1899

Charophyta

Staurastrum gracile Ralfs ex Ralfs 1848

Desmidium swartzii C.Agardh ex Ralfs 1848

Euglenozoa

Lepocinclis acus (O.F.Müller) Marin \& Melkonian, 2003

Miozoa

Apocalathium aciculiferum (Lemmermann) Craveiro, Daugbjerg, Moestrup \& Calado 2016 Ceratium hirundinella (O.F.Müller) Dujardin 1841

Note: 1-Lake Turgoyak, 2-Lake Uvildy, 3-Lake Ilmenskoe, 4-Shershnevskoe Reservoir
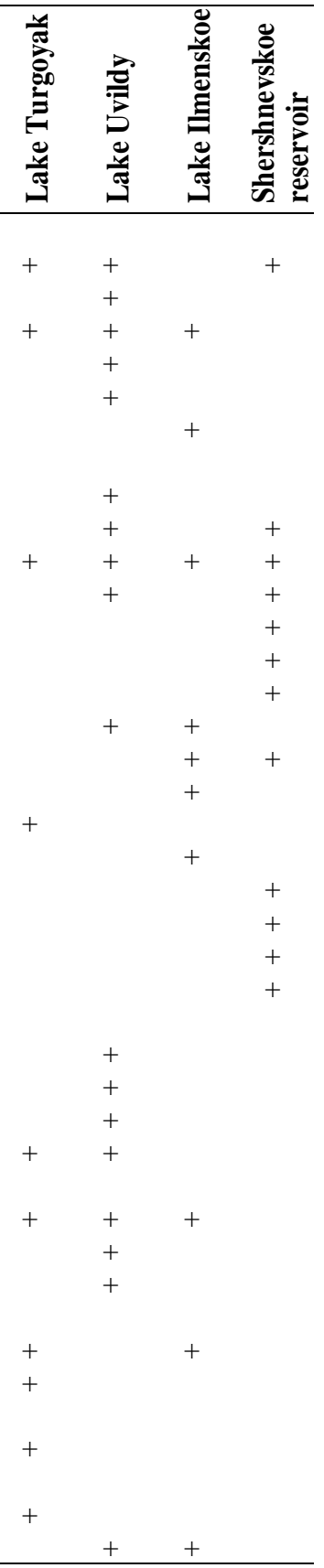

\section{A}

B

C

D

Figure 4. Some dominant phytoplankton species of phytoplankton composition in the studied water bodies (Lake Turgoyak, Lake Uvildy, Lake Ilmenskoe, Shershnevskoe Reservoir) (x200): A. Asterionella formosa Hassall 1830, B. Fragilaria crotonensis Kitton 1865, C. Microcystis aeruginosa (Kützing) Kützing 1846, D. Gloeotrichia echinulata P.G. Richter 1854

The dominant algae species (frequency of more than 30 organisms in the specimen) of the studied lakes are presented in Table 5 and Figure 4. Among the dominant phytoplankton complexes of water bodies with an increasing trophic status, blue-green algae dominate (Lake Ilmenskoe and Shershnevskoe reservoir). Plankton of Cyanobacteria division are the basis for the dominant complex for the eutrophic water body. The dominant complex of the oligotrophic deep Lake Turgoyak is represented by all the microalgae divisions equally.

In summation, there is a relationship between the changing phytoplankton structure and the water body trophic status. Some features could be used to forecast changes in the trophic status. In oligotrophic lakes, algae of 
the Bacillariophyta division play a leading role in the formation of a plankton community. There is also a high species abundance of algae of the Charophyta division, namely, the Desmidiaceae family. Desmids are characterized by high sensitivity to changing environmental conditions. In mesoeutrophic and eutrophic water bodies, the number of Desmids species is significantly lower. An increase in the proportion of Chlorophyta, especially Cyanobacteria, indicates a deterioration in the trophic status of a water body. Algae of the Chlorophyta division predominate in species diversity in eutrophic water bodies. Blue-green algae form the basis of the dominant plankton complex in water bodies with high trophic status.

\section{ACKNOWLEDGEMENTS}

This article was presented at the International Webinar Society for Indonesian Biodiversity \& Sebelas Maret University, Surakarta, Indonesia, 19 December 2020. This research was funded by RFBR and Chelyabinsk Region (Russia), project number 20-45-740005.

\section{REFERENCES}

Al-Kandari M, Al-Yamani F, Al-Rifaie K. 2009. Marine phytoplankton atlas of Kuwait's waters. Lucky Printing Press, Kuwait.

Ansari AA, Gill SS. 2014. Eutrophication: Causes, consequences and control. Volume 2. Springer, Dordrecht. DOI: 10.1007/978-94-0077814-6.

Aquino CAN, Medeiros G, Bortolini JC, Favaretto CCR, Ticiani D, Cerqueira FJ, Bueno NC. 2018. Desmids (Zygnematophyceae) from the littoral zone of an urban artificial lake: Taxonomic aspects and geographical distribution. Acta Limnologica Brasiliensia 30: e202. DOI: $10.1590 / \mathrm{s} 2179-975 X 4417$.

Ayoade AA, Osuala BO, Adedapo TA. 2019. Physico-chemical parameters, chlorophyll a and phytoplankton community as trophic state indices of two tropical lakes, southwestern Nigeria. EurAsian J BioSciences 13 (1): 15-22.

Barinova S, Smith T. 2019. Algae diversity and ecology during a summer assessment of water quality in the Abraham Lincoln Birthplace National Historical Park, USA. Diversity 11 (11): 206. DOI: 10.3390/d11110206.

Bazarova BB, Tashlykova NA, Afonina EY, Kuklin AP, Matafonov PV, Tsybekmitova GT, Gorlacheva EP, Itigilova MT, Afonin AV, Butenko MN. 2019. Long-term fluctuations of the aquatic ecosystems in the Onon-Torey plain (Russia). Acta Ecologica Sinica 39 (2): 157165. DOI: 10.1016/j.chnaes.2018.08.003.

Besedin VB, Vorobyova OI, Gitis MS. 2000. Tourist resources of the Chelyabinsk region. ABRIS, Chelyabinsk. [Russian]

Bogdanov VD, Bogdanova EN, Gavrilov AL, Melnichenko IP, Stepanov LN, Yarushina MI. 2004. Bioresources of aquatic ecosystems of the Polar Urals. Ural Branch of the Russian Academy of Sciences, Yekaterinburg. [Russian]

Chekryzheva TA. 2017. Phytoplankton of lakes in different types of landscape in Southern Karelia (Vendyurskaya group and Zaonezhye). Proceedings of the Karelian Scientific Center of the Russian Academy of Sciences 1: 62-74. DOI: 10.17076/bg378. [Russian]

Coesel PFM. 2001. A method for quantifying conservation value in lentic freshwater habitats using desmids as indicator organisms. Biodiv Conserv 10 (2): 177-187. DOI:10.1023/A:1008985018197.

Downing JA, Watson SB, McCauley E. 2001. Predicting cyanobacteria dominance in lakes. Can J Fish Aquat Sci 58 (10): 1905-1908. DOI: 10.1139/f01-143.

Eremkina TV. 2010. Structure and functioning of phytoplankton of lakes in the north part of the Uvildinskaya zone (Chelyabinsk region) under anthropogenic eutrophy. [Dissertation]. Research institute of aquatic bioresources and aquaculture, Ekaterinburg. [Russian]
Federal Law of March 14, 1995 N 33-FZ "On Specially Protected Natural Areas". [Russian]

Gao F, Qiao Y, Wang W, Lv S. 2020. Identification and evaluation of factors affecting the eutrophication of Wuxing lake. International $\mathrm{J}$ Design Nature Ecodynamics 15 (4): 603-608. DOI: 10.18280/ijdne.150419.

Guiry MD, Guiry GM. 2020. AlgaeBase. World-wide electronic publication. National University of Ireland, Galway. https://www.algaebase.org; searched on 20 June 2020.

Hall R, Smol J. 1999. Diatoms as indicators of lake eutrophication. In: Stoermer E, Smol J (eds.). The Diatoms: Applications for the Environmental and Earth Sciences. Cambridge University Press, Cambridge. DOI:10.1017/CBO9780511613005.007.

Ismest'eva LR, Moore MV, Hampton SE, Ferwerda CJ, Gray DK, Woo KH, Pislegina HV, Kraschuk RS, Shimaraeva SV, Silow EA. 2015. Lake-wide physical and biological trends associated with warming in Lake Baikal. J Great Lakes Res 42: 6-17. DOI: 10.1016/j.jglr.2015.11.006.

Jensen J, Jeppesen E, Olrik K, Kristensen P. 1994. Impact of nutrients and physical factors on the shift from cyanobacterial to chlorophyte dominance in shallow Danish lakes. Canadian J Fisheries and Aquatic Sciences 51 (8): 1692-1699. DOI: 10.1139/f94-170.

Komulaynen SF. 2018. Phytoperiphyton of water bodies and water courses of the State Nature Reserve «Kivach» (Republic of Karelia, Russia). Nat Conserv Res 3 (3): 46-60. DOI: 10.24189/ncr.2018.029. [Russian]

Kostryukova AM, Mashkova IV, Trofimenko VV, Vasilieva EI. 2019. Taxonomic structure of phytoplankton in Shershnevskoe Reservoir (Chelyabinsk, Russia), an artificial lake. IOP Conf Ser Earth Environ Sci 351 (1): 012001. DOI: 10.1088/1755-1315/351/1/012001

Kostryukova A, Mashkova I, Shchelkanova E, Trofimenko V, Kornilova A. 2020. Analysis of water quality of rivers and reservoirs in Chelyabinsk region, South Ural. Intl J Geomate 18 (67): 120-127. DOI: $10.21660 / 2020.67 .9163$.

Levit AI. 2005. South Ural: geography, ecology, nature management. South Ural Book Publishing House, Chelyabinsk. [Russian].

Lisovskaya N. 2020. Lake Turgoyak-the younger brother of the Baikal near Miass. https://www.itinari.com/lake-turgoyak-the-youngerbrother-of-the-baikal-near-miass-lgp0.

Ma J, Qin B, Paerl HW, Brookes JD, Wu P, Zhou J, Deng J, Guo J, Li Z. 2015. Green algal over cyanobacterial dominance promoted with nitrogen and phosphorus additions in a mesocosm study at Lake Taihu, China. Environ Sci Pollut Res 22 (7): 5041-5049. DOI: 10.1007/s11356-014-3930-4.

Makeeva EG, Denisova OO. 2017. Taxonomic diversity of algae of water objects in the vicinities of Lake Svetloe, Ergaki Ridge. In: Nepomniachtchi VV (ed.). Scientific research in nature reserves and national parks of South Siberia. Siberian Branch of the Russian Academy of Sciences, Novosibirsk.

Malakhov Y, Kryvosheia O, Tsarenko P. 2017. Microalgae of polk; rotected lakes of Northwestern Ukraine. Polish Bot J 62 (1): 61-76. DOI: $10.1515 / \mathrm{pbj}-2017-0008$.

Malysheva AA, Krivina ES, Kuzmina KA. 2018. The algal composition and structure of the Yaitskoe Lake (Samara region, Russia). Nat Conserv Res 3 (3): 70-79. DOI: 10.24189/ncr.2018.042.

Mashkova I, Kostryukova A, Shchelkanova E, Trofimenko V. 2021 Short Communication: Zooplankton as indicator of trophic status of lakes in Ilmen State Reserve, Russia. Biodiversitas 22 (3): 1448-1455. DOI: 10.13057/biodiv/d220348.

Ministry of ecology of the Chelyabinsk region. 2019. Comprehensive report on the state of the environment of the Chelyabinsk region in 2019. http://www.mineco174.ru/htmlpages/Show/protectingthepublic. [Russian]

Namsaraev Z, Melnikova A, Komova A, Ivanov V, Rudenko A, Ivanov E. 2020. Algal bloom occurrence and effects in Russia. Water 12 (1): 2020285. DOI: 10.3390/w12010285.

Rakocevic-Nedovic J, Hollert H. 2005. Phytoplankton community and chlorophyll a as trophic state indices of Lake Skadar (Montenegro, Balkan). Environ Sci Pollut Res 12 (3): 146-152. DOI: 10.1065/espr2005.04.241.

Nowakowski AB. 2004. Possibilities and principles of operation of the software module "Graphs". Automation of Scientific Research 27: 2 29. [Russian]

Paulino AI, Larsen A, Bratbak G, Evens D, Erga SR, Bye-Ingebrigtsen E, Egge JK. 2018. Seasonal and annual variability in the phytoplankton community of the Raunefjord, west coast of Norway from 2001-2006. 
Mar Biol Res 14 (5): 421-435. DOI: 10.1080/17451000.2018.1426863.

Pratiwi H, Damar A, Sulistiono. 2018. Phytoplankton community structure in the Estuary of Donan River, Cilacap, Central Java, Indonesia. Biodiversitas 19 (6): 2104-2110. DOI 10.13057/biodiv/d190616.

Pratiwi NTM, Imran Z, Ayu IP, Iswantari A, Wulandari DY. 2020. The phosphorus load and the variation of the trophic states of cirata reservoir (West Java, Indonesia) from 1988 to 2017. Biodiversitas 21 (9): 4176-4183. DOI: 10.13057/biodiv/d210931.

Pearsall WH. 1932. Phytoplankton in the English lakes. II. The composition of the phytoplankton in relation to dissolved substances. Ecology 20 (2): 241-262. DOI: 10.2307/2256077.

Setyono P, Himawan W. 2018. Analyses of bioindicators and physicochemical parameters of water of Lake Tondano, North Sulawesi Province, Indonesia. Biodiversitas 19 (3): 817-824. DOI: 10.13057/biodiv/d190315.

Sharov AN. 2020. Phytoplankton of cold-water lake ecosystems under the influence of natural and anthropogenic factors. [Dissertation]. SanktPetersburg Research Center for Environmental Safety of the Russian Academy of Sciences, Sankt-Petersburg. [Russian]

Snit'ko LV, Sergeeva RM. 2003. Algae of various types of water bodies in the east part of the South Ural. ESR Ub of RAS, Miass. [Russian]

Snit'ko LV. 2009 Ecology and succession of phytoplankton of lakes of the South Ural. ESR and SPC Ub of RAS, Miass. [Russian]

Snit'ko LV, Snit'ko VP. 2012. Phytoplankton of deep-water lakes of Southern Ural during a high level of water (Russia). Algologia 22 (3): 275-285. DOI:10.1615/InterJAlgae.v15.i1.20 [Russian]

Song Y, Qi J, Liu L, Deng L, Liu H, Bai Y, Liu H, Qu J. 2019. Eutrophication status and phytoplankton community structure in Chenghai Lake in summer and winter Huanjing Kexue Xuebao. Acta Scientiae Circumstantiae 39 (12): 4106-4113. DOI: 10.13671/j.hjkxxb.2019.0308.

Suda H, Tanaka M, Oyagi M, Nobori M, Yagi A. 2016. Water quality and compositions of the phytoplankton and zooplankton before and after building construction in Lake Fukami-ike, Japan. Intl J GEOMATE 10 (4): 1983-1988. DOI: 10.21660/2016.22.5140.

Trifonova IS. 1990. The ecology and succession of lake phytoplankton. Nauka, Leningrad. [Russian]

Veisberg EI, Lagunov AV, Smagin AI. 2015. Protected biological species of Nature Sanctuary «Lake Uvildy» (composition, prognosis of condition). Vestnik Orenburg State University 3 (178): 159-163. [Russian]

Viaroli P, Nizzoli D, Pinardi M, Soana E, Bartoli M. 2015. Eutrophication of the Mediterranean Sea: a watershed-cascading aquatic filter approach. Rendiconti Lincei 26 (1): 13-23. DOI: 10.1007/s12210014-0364-3.

Wang J, Wu S, Fan B, Chen W. 2020. Distribution features of phytoplankton and its correlation with environmental factors of Baima Lake. IOP Conf Ser Mater Sci Eng 730 (1): 012055. DOI: 10.1088/1757-899X/730/1/012055.

Weckström K, Korhola A, Weckström J. 2007. Impacts of eutrophication on diatom life forms and species richness in coastal waters of the Baltic Sea. Ambio 36 (2-3): 155-160. DOI: 10.1579/00447447(2007)36[155:IOEODL]2.0.CO;2.

WoRMS Editorial Board. 2019. World register of marine species. http://www.marinespecies.org; [20 June 2020]

Yang Y, Du C, Qian Z, Jiang C, Chen H, Yu G, Li Y. 2020. Phytoplankton community structure and its influencing factors in Nanhan Polder Area of Dongting Lake. Res Environ Sci 33 (1): 14754. DOI: 10.13198/j.issn.1001-6929.2019.06.17.

Yarushina MI, Tanaeva GV, Eremkina TV. 2004. Algae flora of water bodies of the Chelyabinsk region. Ural Branch of Russian Academy of Sciences, Ekaterinburg. [Russian]

Zakharov SG. 2018. Dynamics of environmental state of recreational lakes in South Ural (as exemplified by lakes Turgoyak, Bolshoy Kisegach, Elovoe). Proceeding of Actual Issues of Modern Natural Science in South Ural. Chelyabinsk State University, Russia, 21 December 2018. [Russian] 